\title{
The mechanical degradation of land surface and the present state of the loess "islands" plant cover of Chernihiv Polesie (Ukraine)
}

\author{
Oleksandr Lukash ${ }^{1 *}$, Oleksandr Yakovenko ${ }^{1}$, Iryna Miroshnyk ${ }^{2}$ \\ ${ }^{1}$ Department of Ecology and Nature Conservation, ${ }^{2}$ Department of Languages and Methodology, \\ T. Shevchenko National University "Chernihiv Collegium", \\ Hetman Polubotko 53 St, 14013 Chernihiv, Ukraine, \\ *e-mail: lukash2011@ukr.net
}

Received: 23 March 2018 / Accepted: 18 June 2018

\begin{abstract}
The causes of the mechanical degradation of the loess lands of Chernihiv Polesie have been determined, in particular, the ability of the loess to be washed out and subside easily, deforestation (the end of the 13th - the beginning of the 14th centuries) and the excessive increase of the anthropogenic pressure on the agricultural lands (the end of the 19th - the beginning of the 21st centuries). It has been cleared that the degradation of the loess "islands" soils of Chernihiv Polesie is manifested in the form of erosion and suffusion. The areas at the fifth stage of erosion prevail. The largest percentage of the eroded areas is on the Mykhailo-Kotsiubynsk and Ripky-Chernihiv loess "islands". The lands with suffusion forms dominate on the Berezna-Mena-Sosnytsia loess "island". Long-term use of the arable lands contributed to the increase of erosion and suffusion forms of the relief. The potential places of the beginning of the mechanical degradation are post-sowing, neglected lands, which were repeatedly violated mechanically. The plant communities, which are the indicators of different stages of mechanical degradation of the lands, have been identified. The plant communities of Digitario sanguinalis-Eragrostietea minoris Mucina, Lososová et Šilc 2016 and Bidentetea Tx. et al. ex von Rochow 1951 are the indicators of eroded lands at the stages of formation, expansion and deepening of washouts. The phytocenoses of Bidentetea tripartiti are the indicators of the initial stages of suffusion, and the complexes of Magnocaricetalia are the indicators of suffusion increase and deepening. Over the past 120 years, there has been a slight increase in the area occupied by plant communities other than agrocenoses on the loess "islands" due to the anti-erosion planting of Pinus sylvestris and Robinia pseudoacacia. The agronomic, fitomeliorative and prohibitive measures that can slow down the pace of the mechanical degradation of the loess lands of Chernihiv Polesie have been suggested.
\end{abstract}

Keywords: Chernihiv Polesie, loess "island", erosion, suffusion, vegetation.

\section{Introduction}

The current state of the land use in Ukraine does not meet the requirements of rational nature management. The ecologically acceptable ratio of the arable land areas and natural forage lands, which negatively affects the stability of the agro-landscape, has been broken. Among all the types of degradation in most cases the first place should be given to water erosion, because under its influence the soils permanently lose its profile and frame structure. Erosion processes interfere with the functioning of ecosystems and economic activity of people.
The area of the agricultural lands in Ukraine, which is affected by erosion, is 13.3 million hectares. The processes of linear erosion and raving are intensively developing. The area of ravines is 141.1 thousand hectares, and their number exceeds 500 thousand. The individual ravine-gulch systems are characterized by the intensity of erosion that exceeds the average indices (Baliuk \& Tovazhnianskyi, 2010).

In the Chernihiv region there are 65.7 thousand hectares of land suffering from erosion. In Chernihiv Polesie erosion processes are observed mainly in the loess "islands" (Bezdukhov, 2013). 
One of the trends in anthropogenic landscape changes is synanthropization of vegetation. The weakening of the competitive relations of the species due to the violation of natural habitats, as well as the ease of displacement of the diaspores of synanthropic species, are the direct causes of anthropogenic changes in a vegetation cover. The anthropogenic transformation of vegetation is both a cause and a consequence of land degradation.

The study of loess "islands" was conducted on the territory of Eastern Europe (Russia, Ukraine) only to determine their genesis, the history of their development and their landscape structure (Milkov, 1964; Akhromeiev, 2008; Budko, 2009). The degree of the mechanical degradation of these lands and its relationship with the state of the loess "islands" vegetation have not been investigated. The goal of our study is to investigate the causes and rate of the mechanical degradation of the land, the current state of the loess "islands" plant cover of Chernihiv Polesie (Ukraine) as one of the indicators of this process, to propose the measures to protect the lands from the mechanical degradation.

\section{Study area}

According to the physico-geographical zoning of Ukraine (Marynych et al., 2003), the northwestern part of the Chernihiv region is situated within the boundaries of Chernihiv Polesie. In geostructural relation Chernihiv Polesie is situated within the limits of three structural formations: the eastern slope and the foot of the Ukrainian crystalline shield, the western slope of the Voronezh crystalline massif and the Dnipro-Donets cavity located between them.

Modern landscapes of Chernihiv Polesie were formed in the middle and late quaternary epochs. The landscape structure of this territory is dominated by the Polesie landscape complexes (63\% of the region's area). The landscape complexes with forest-steppe features have a significant (up to $18 \%$ ) distribution. They occur fragmentarily and characteristic to so-called loess "islands". These landscape complexes are spread in a strip located to the north of the Desna River (Fig. 1).

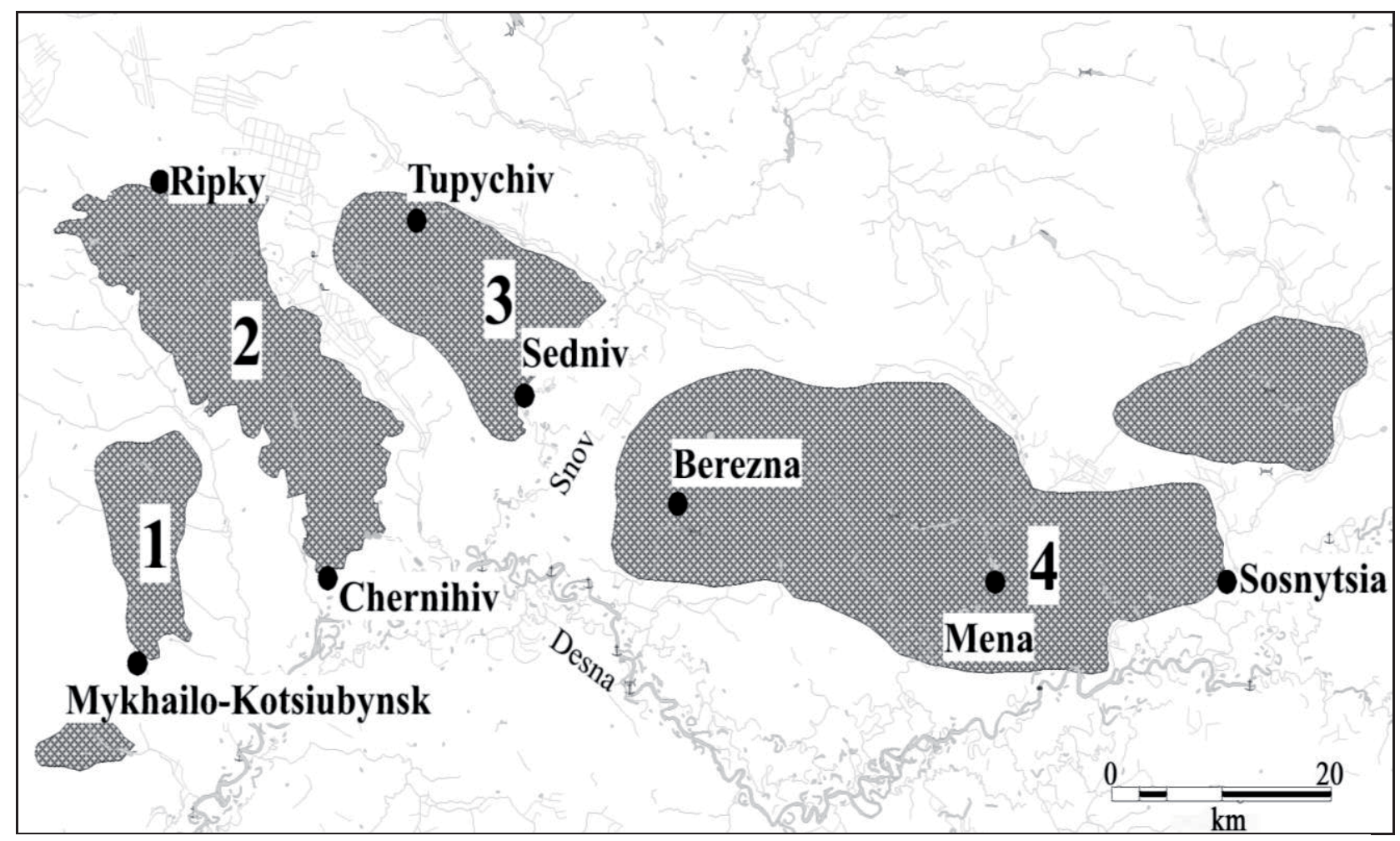

Figure 1. Loess "islands" of Chernihiv Polesie: 1 - Mykhailo-Kotsiubynsk, 2 - Ripky-Chernihiv, 3 - Sedniv-Tupychiv, 4 - BereznaMena-Sosnytsia 
The "islands" are elevated above the surrounding area and have a different area: Berezna-Mena-Sosnytsia $1012 \mathrm{~km}^{2}$, Ripky-Chernihiv - $508 \mathrm{~km}^{2}$, Sedniv-Tupychiv $246 \mathrm{~km}^{2}$, Mykhailo-Kotsiubynsk - $130 \mathrm{~km}^{2}$. The soil cover of the loess "islands" is grey and dark grey light-loam soils.

According to the paleobotanical data (Pashkevych, 1971), in the late-glacial and post-glacial periods on the territory of loess "islands", as well as Chernihiv Polesie, broadleaved forests prevailed. According to the archaeologists, the opening up of the loess areas by a man began about 2000 years ago. According to the results of the archaeological researches, it is known that since the end of the 13th - the beginning of the 14th centuries the forest type of the loess "islands" landscapes has been replaced by the landscape of fields and pastures (Veremeichyk, 2010). The intensive and long-term development of agriculture on the loess "islands" has become the determining factor in the development of the mechanical degradation of their soils.

\section{Material and methods}

The materials for the article were collected during the field research of the loess "islands" of Chernihiv Polesie during 2008-2017. In the course of the work, the landscape studies (194 releves) were conducted. The topographic maps of the different time (Schubert \& Tuchkov, 1916; Atlas..., 1978) and satellite images of the loess "islands" territory were used.

The field study of the vegetation was carried out by the geobotanical methods (Korchahin, 2012). 308 phytosociological releves were made. Syntaxa were identified according to Mucina et al. (2016), Matuszkiewicz (2001) (for natural vegetation), Solomakha et al. (1992) (for synanthropic vegetation). Syntaxon names are ordered according to Mucina et al. (2016)

To find out the causes of the mechanical degradation of the land the methods of historical geography (Zhekulin, 1982) were used. The vector maps of the spread of loess "islands", erosion dismemberment and suffusion-sedimentary forms of vegetation were created.

\section{Results and discussion}

An anthropogenic influence on the loess "islands" increased at the end of the 19th - the beginning of the 21 st centuries. The use of heavy agricultural machinery and violation of the lands ploughing regime on the slopes contributed to the local destruction of the soil cover.

The mechanical degradation processes of the loess "islands" of Chernihiv Polesie are manifested in the form of erosion and suffusion. Figure 2 shows that the area of the erosion forms of the relief has increased over the past
120 years from $1 \%$ to $1.5 \%$. The largest percentage of eroded areas is on the Mykhailo-Kotsiubynsk and RipkyChernihiv loess "islands".

The erosion forms of the relief are concentrated on the edge regions of the "islands". The loess "islands" differ in the average index of the erosion dismemberment. The Mykhailo-Kotsiubynsk loess "island" has the largest average index of the erosion dismemberment $\left(1.3 \mathrm{~km} / \mathrm{km}^{2}\right)$, the Berezna-Mena-Sosnytsia loess "island" - the smallest $\left(0.2 \mathrm{~km} / \mathrm{km}^{2}\right)$.

The eroded areas at different stages of their development were found in all the loess "islands" (Table 1). We observe the general tendency of such places predominance at the fifth stage.

We set the time limits for the first and second erosion stages on the loess "islands". They are respectively 1-4 and 5-9 years old.

The loess thickness of the territories, exposed to erosion, is represented by more or less typical loess, loess-like loams, sandy loams. In comparison with the loess of the middle and especially the southern latitudes of Ukraine, the loess of Chernihiv Polesie is always sandy. The degree of its sandiness varies greatly, as a result it often passes into sandy loams and even loess-like sands. Occasionally, more clayer loess can be met. Carbonate also occurs in the form of nodules with a maximum diameter of 5-7 cm (the Mykhailo-Kotsiubynsk loess "island"), in the form of depositions along the cracks of shrinking (the SednivTupychiv loess "island"), is unevenly filled with iron compounds in the form of stripes, free designs and spots (the Sedniv-Tupychiv and Ripky-Chernihiv loess "islands").

The inter-river spaces and weakly drained regions of the loess "islands" of Chernihiv Polesie are also characterized by suffusion forms (cavities, "steppe saucers"), which have an anthropogenic natural origin. They are formed as a result of chemical-mechanical suffusion (subsidence), often under the influence of heavy agricultural machinery. Suffusion develops in the loess rocks where the carbonate cementing substance dissolves and the clay particles are simultaneously carried out (Lanko, 1958).

The places of significant suffusion forms development - it is mainly overflood-plain territories of Chernihiv Polesie. First of all, these are the plains of high anthropogenic terraces, which in modern landscapes have become saucer-like territories on the loess alluvium. Forests are absent here today, but the grey forest soils formed on sandy loess-like loams preserved. Such areas are developed on each loess "island" near the watercourses. We observe the largest plain-hollow areas $\left(452 \mathrm{~km}^{2} ; 44.7 \%\right)$ with suffusion forms on the Berezna-Mena-Sosnytsia "island": on the right bank of the Desna River (the outskirts of the Sosnytsia and Berezna villages) in the valley of the Mena River. Smaller areas of suffusion were found in the valley of the Zamhlai River: on the Ripky-Chernihiv (98 km²; 19.3\%) 


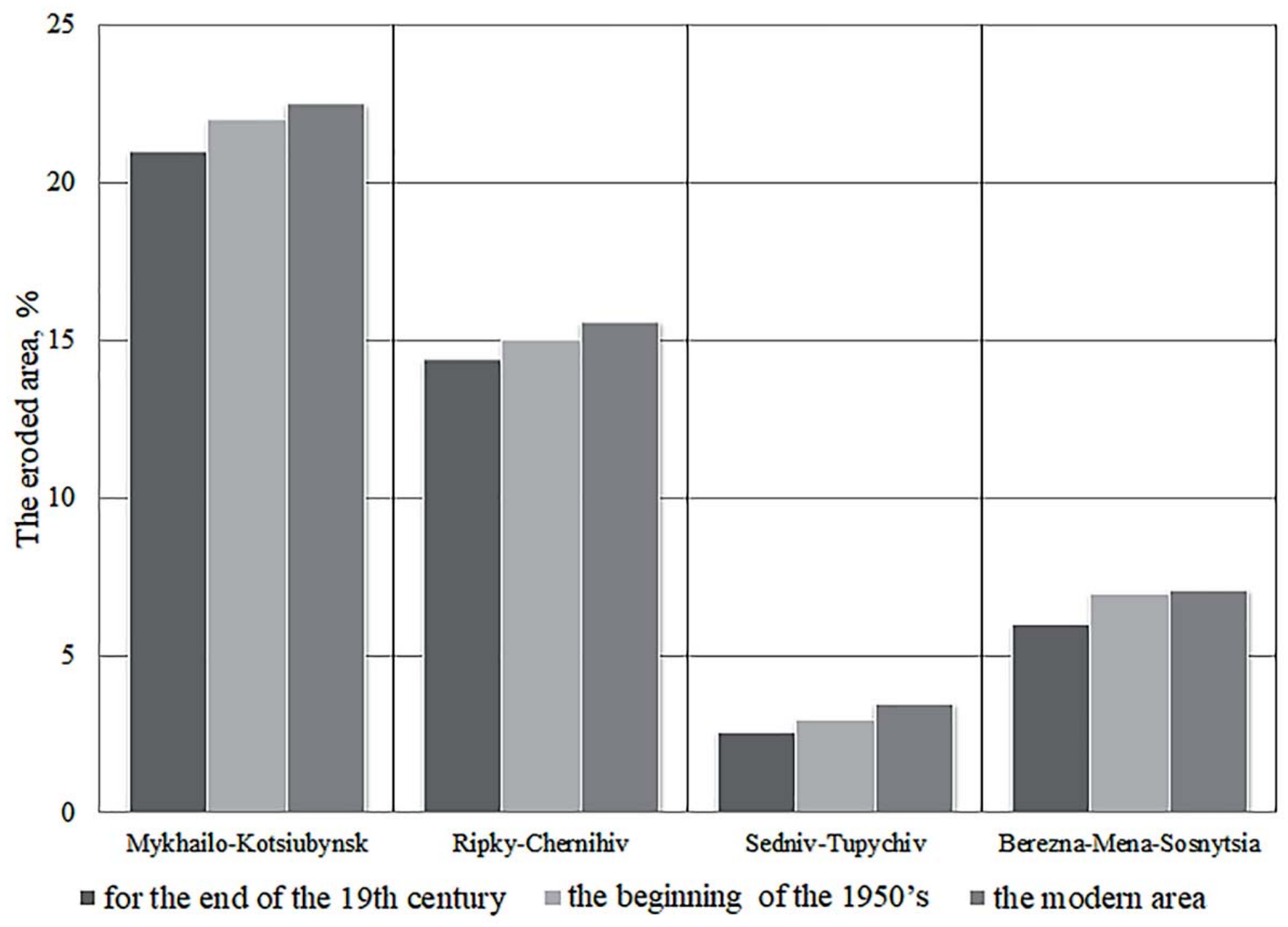

Figure 2. Dynamics of the eroded loess "island" areas of Chernihiv Polesie (\%)

Table 1. Area ratio of different stages of erosion on the loess "islands" of Chernihiv Polesie

\begin{tabular}{|l|c|c|c|c|}
\hline \multirow{2}{*}{ The stages of water erosion } & \multicolumn{3}{|c|}{ The part of the general eroded area on the loess territory, \% } \\
\cline { 2 - 5 } & $\begin{array}{c}\text { Mykhailo- } \\
\text { Kotsiubynsk }\end{array}$ & Ripky-Chernihiv & Sedniv-Tupychiv & $\begin{array}{c}\text { Berezna-Mena- } \\
\text { Sosnytsia }\end{array}$ \\
\hline $\begin{array}{l}\text { I - formations of washouts on the } \\
\text { slopes }\end{array}$ & 10 & 9 & 7 & 6 \\
\hline $\begin{array}{l}\text { II - expansion and deepening } \\
\text { of washouts }\end{array}$ & 5 & 6 & 5 & 6 \\
\hline III - branching of ravines & 15 & 15 & 17 & 18 \\
\hline IV - deep erosion & 9 & 8 & 6 & 4 \\
\hline $\begin{array}{l}\text { V - transforming a ravine into } \\
\text { a gulch }\end{array}$ & 61 & 62 & 65 & 66 \\
\hline
\end{tabular}


and Sedniv-Tupychiv $\left(90 \mathrm{~km}^{2} ; 36.6 \%\right)$ loess "islands". On the Mykhailo-Kotsiubynsk loess "island" the suffusionsubsidence forms are widespread $\left(12 \mathrm{~km}^{2} ; 9.2 \%\right)$, mostly on a weakly drained part of the watershed. The so-called "Karkhiv circles" - the terrain where saucer-like cavities are concentrated in the relief (Fig. 4).

The arable lands prevailed on the territory of all loess "islands" over the past 120 years (Fig. 3). Over the past 120 years the amount of the arable lands on the loess "islands" increased by $2-7 \%$. In accordance with the existing conditions of the arable lands, certain vegetation communities formed.

The ratio of areas occupied by the communities of one or another vegetation class is given in Table 2 .

The vegetation map charts of the loess "islands" are represented in Figures 4-6.

The plant communities of cereal crops belonging to the Papaveretea rhoeadis S. Brullo et al. 2001 class predominates in the plant cover of these territories. The dynamic aspects of the segetal vegetation development have significant differences from the development in natural phytocoenoses (Solomakha, 1992). The only stable element in agricultural crops is a significant amount of weed seeds in the soil. The stability of the seed "bank" of the soil of a particular field is not an obstacle to the various manifes- tations of the weed synusiae of agrophytocenoses depending on the field culture. The differences between them are the basis for assigning agrophytocenoses of one field in the crop rotation to different syntaxa due to the rank from the association to the order. Let's examine it in the examples.

Significant share in in the winter wheat and rye crops have weeds, which are diagnostic species of the Aperetalia spicae-venti J.Tx. et Tx. in MalatoBeliz et al. 1960 (Consolida regalis S.F.Gray, Tripleurospermum inodorum (L.) Sch.Bip., Viola arvensis Murray, Crepis tectorum L.) order, as well as diagnostic types of this class alliances: Aperion spica-venti R.Tx. ap. Oberd 1949 (Apera spica-venti (L.) P. Beauv., Equisetum arvense L., Lamium purpureum L.) and Centaurion cyani (Centaurea cyanus L., Scleranthus annus L., Vicia angustifolia Reichard).

When changing the sown areas of cereal crops by the cultivated ones (e.g., potatoes), the communities of the the alliance of Panico-Setarion Siss. are formed. It is diagnosed by such species as Barbarea vulgaris R.Br. ex W.T. Aiton, Equisetum arvense L., Raphanus raphanistrum L., Setaria viridis (L.) P.Beauv.

A part of the agricultural land is occupied by the communities Agropyretalia intermedio-repentis T. Müller et Görs 1969 of the Artemisietea vulgaris Lohmeyer et al. in Tx. ex von Rochow 1951 class. These are ruderal and

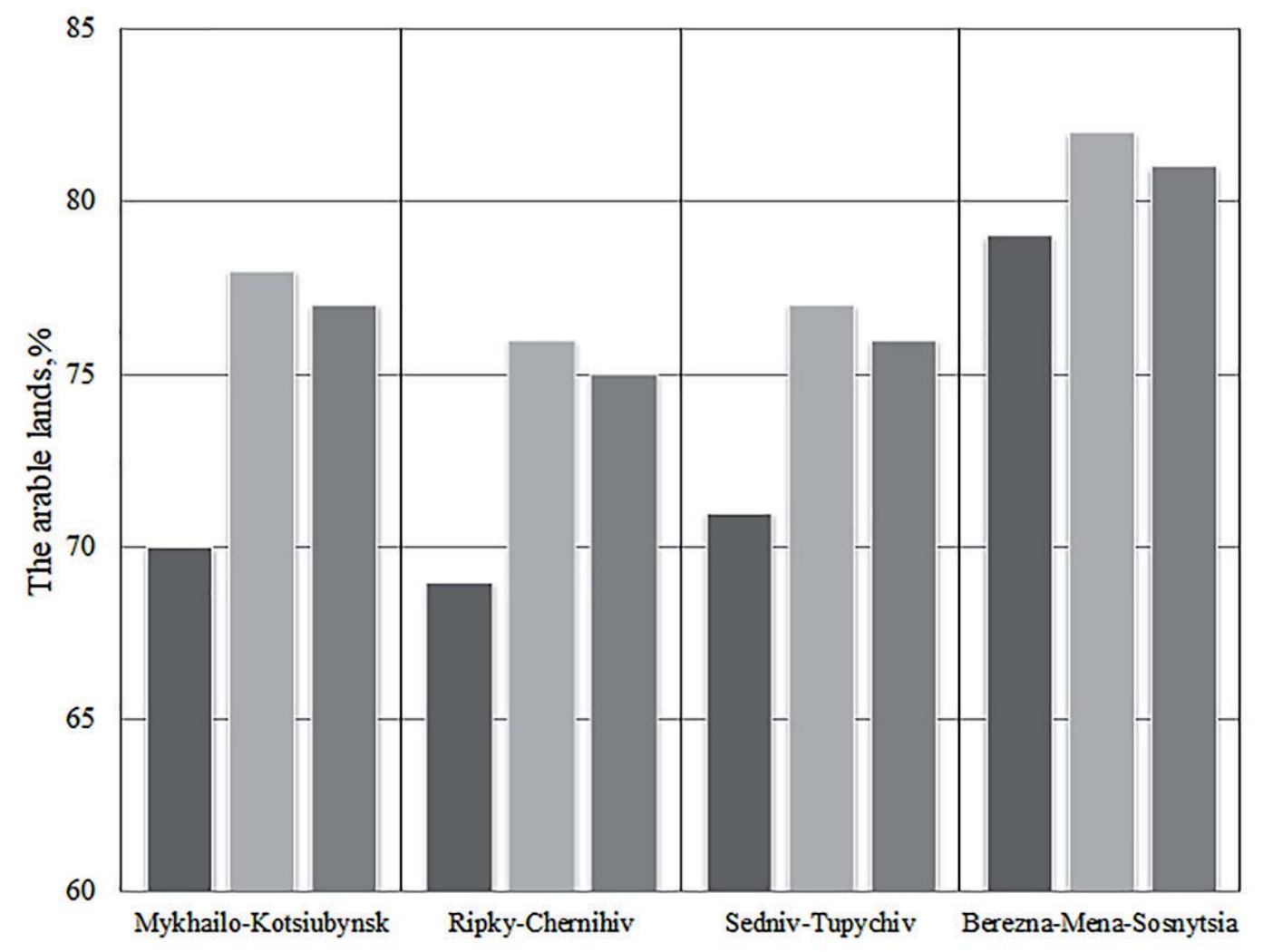

Figure 3. Dynamics of changes in the area of arable land of the loess "islands" of Cernihiv Polesie 
Table 2. Percentage ratio of the vegetation classes areas on the loess "islands" of Chernihiv Polesie

\begin{tabular}{|c|c|c|c|c|}
\hline \multirow[b]{2}{*}{ Vegetation class } & \multicolumn{4}{|c|}{ Loess "island" } \\
\hline & $\begin{array}{c}\text { Mykhailo- } \\
\text { Kotsiubynsk }\end{array}$ & Ripky-Chernihiv & Sedniv-Tupychiv & $\begin{array}{l}\text { Berezna-Mena- } \\
\text { Sosnytsia }\end{array}$ \\
\hline Lemnetea O. de Bolòs et Masclans 1955 & $<1$ & 4 & 1 & 3 \\
\hline Potamogetonetea Klika in Klika et Novák 1941 & 0 & $<1$ & $<1$ & $<1$ \\
\hline $\begin{array}{l}\text { Phragmito-Magnocaricetea Klika in Klika et Novak } \\
1941\end{array}$ & $<1$ & 1 & 2 & 3 \\
\hline Molinio-Arrhenatheretea R.Tx. 1937 & 3 & 5 & 2 & 7 \\
\hline Trifolio-Geranietea Th. Müller 1962 & $<1$ & $<1$ & $<1$ & $<1$ \\
\hline Crataego-Prunetea Tx. 1962 & 0 & $<1$ & 0 & 0 \\
\hline Salicetea purpureae Moor 1958 & $<1$ & 1 & 1 & 1 \\
\hline $\begin{array}{l}\text { Alnetea glutinosae Br.-Bl. et Tx. ex Westhoff et al. } \\
1946\end{array}$ & 1 & 2 & 3 & 5 \\
\hline $\begin{array}{l}\text { Carpino-Fagetea sylvaticae Jakucs ex Passarge } \\
1968\end{array}$ & 1 & $<1$ & $<1$ & $<1$ \\
\hline $\begin{array}{l}\text { Quercetea robori-petraeae Br.-B1. et Tx. ex Oberd. } \\
1957\end{array}$ & $<1$ & $<1$ & $<1$ & $<1$ \\
\hline Pyrolo-Pinetea sylvestris Korneck 1974 & $<1$ & 3 & 1 & $<1$ \\
\hline Robinietea Jurko ex Hadač et Sofron 1980 & 1 & $<1$ & 2 & $<1$ \\
\hline $\begin{array}{l}\text { Epilobietea angustifolii Tx. et Preising ex von } \\
\text { Rochow } 1951\end{array}$ & 5 & 4 & 6 & 5 \\
\hline Crataego-Prunetea Tx. $1962-$ & 1 & $<1$ & $<1$ & $<1$ \\
\hline $\begin{array}{l}\text { Artemisietea vulgaris Lohmeyer et al. in Tx. ex von } \\
\text { Rochow } 1951\end{array}$ & 6 & 8 & 10 & 12 \\
\hline Bidentetea Tx. et al. ex von Rochow 1951 & $<1$ & $<1$ & $<1$ & $<1$ \\
\hline $\begin{array}{l}\text { Digitario sanguinalis-Eragrostietea minoris } \\
\text { Mucina, Lososová et Šilc } 2016\end{array}$ & 9 & 4 & 2 & 3 \\
\hline Papaveretea rhoeadis S. Brullo et al. 2001 & 69 & 65 & 68 & 59 \\
\hline
\end{tabular}

semi-ruderal communities of hemicryptophytes in dry anthropogenic or natural areas. The characteristic species of this class: Elytrigia repens (L.) Nevski, Poa angustifolia L., Convolvulus arvensis L. The communities chose the locations with compressed soil. It does not prevent from the creation of mono-dominant communities of Elytrigia repens (L.) Nevski on the arable lands. The largest area of this class is located on the territory of the Berezna-MenaSosnytsia and Sedniv-Tupychiv loess "islands" (9\% and $7 \%$ accordingly).

The communities of thermophilous grass-rich anthropogenic vegetation rich in summer-annual C4 species, belonging to the class of Digitario sanguinalis-Eragrostiet- ea minoris Mucina, Lososová et Šilc 2016, make up 2-9\% of the total vegetation of the loess "islands". They are formed on the loose substrates of open spaces, especially in the places of the initial erosion of lands.

The smallest areas (less than 1\%; Table 2) are occupied by the synanthropic vegetation of the following classes $B i$ dentetea Tx. et al. ex von Rochow 1951 (the areas on the overmoistened mostly nitrified substrates near reservoirs, cattle farms, along watercourses, mainly in the open areas at the initial stages of suffusion) and Epilobietea angustifolii Tx. et Preising ex von Rochow 1951 (grass communities of forest fellings). The ruderal forest nitrophilic communities of the Robinietea Jurko ex Hadač et Sofron 1980 class, 


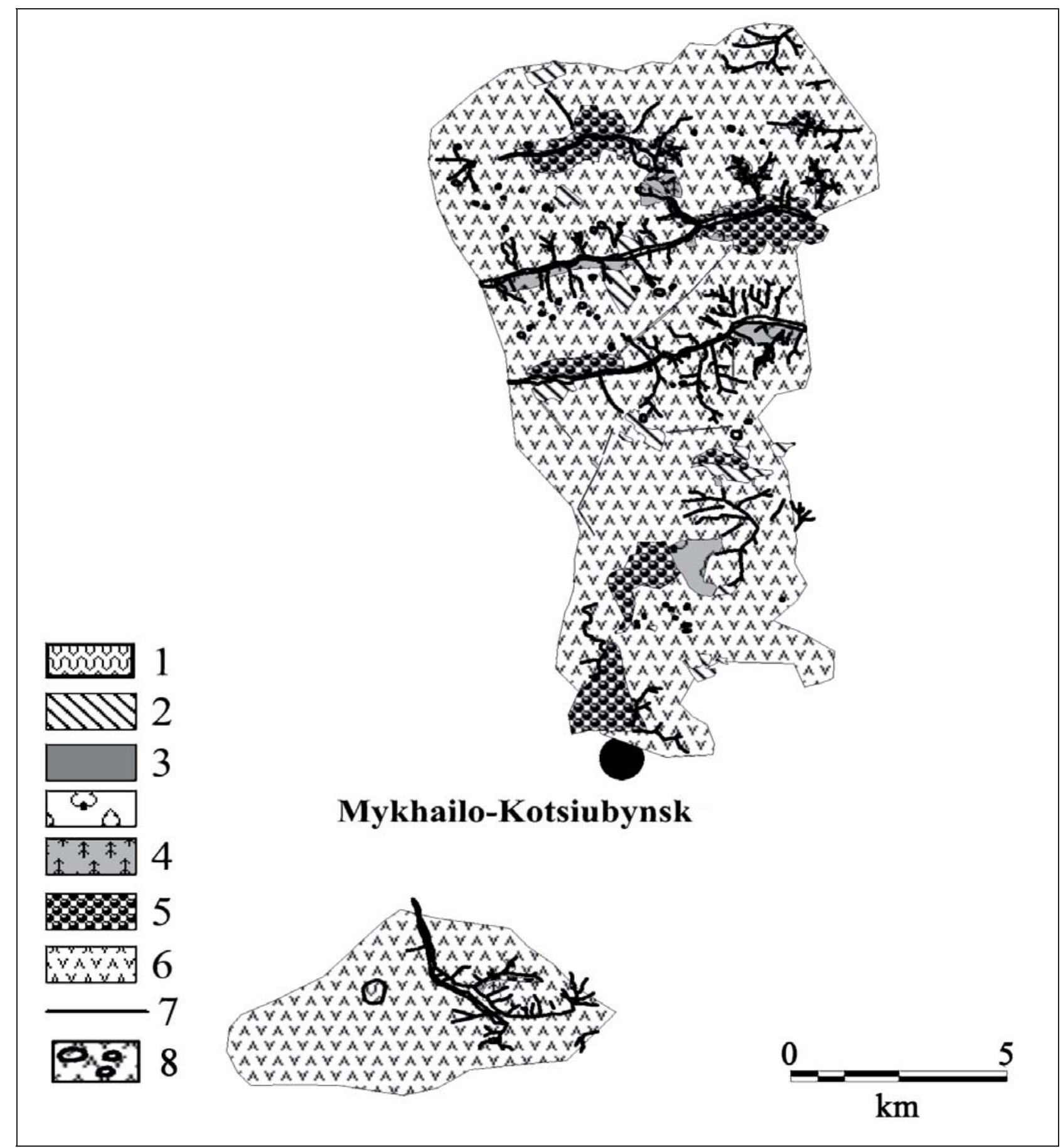

Figure 4. Vegetation map chart of the Mykhailo-Kotsiubynsk loess "islands": 1- complex Phragmito-Magnocaricetea, Alnetea glutinosae, Lemnetea, Potamogetonetea, Salicetea purpureae, and Bidentetea; 2 - complex Molinio-Arrhenatheretea and Trifolio-Geranietea; 3 - complex Carpino-Fagetea sylvaticae and Quercetea robori-petraeae; 4 - complex PulsatilloPinetea sylvestris and Epilobietea angustifolii; 5 - complex Crataego-Prunetea, Robinietea, Agropyretea repentis, Digitario sanguinalis-Eragrostietea minoris; 6 - Papaveretea rhoeadis. Mechanical degradation: 7 - erosion, 8 - suffusion 


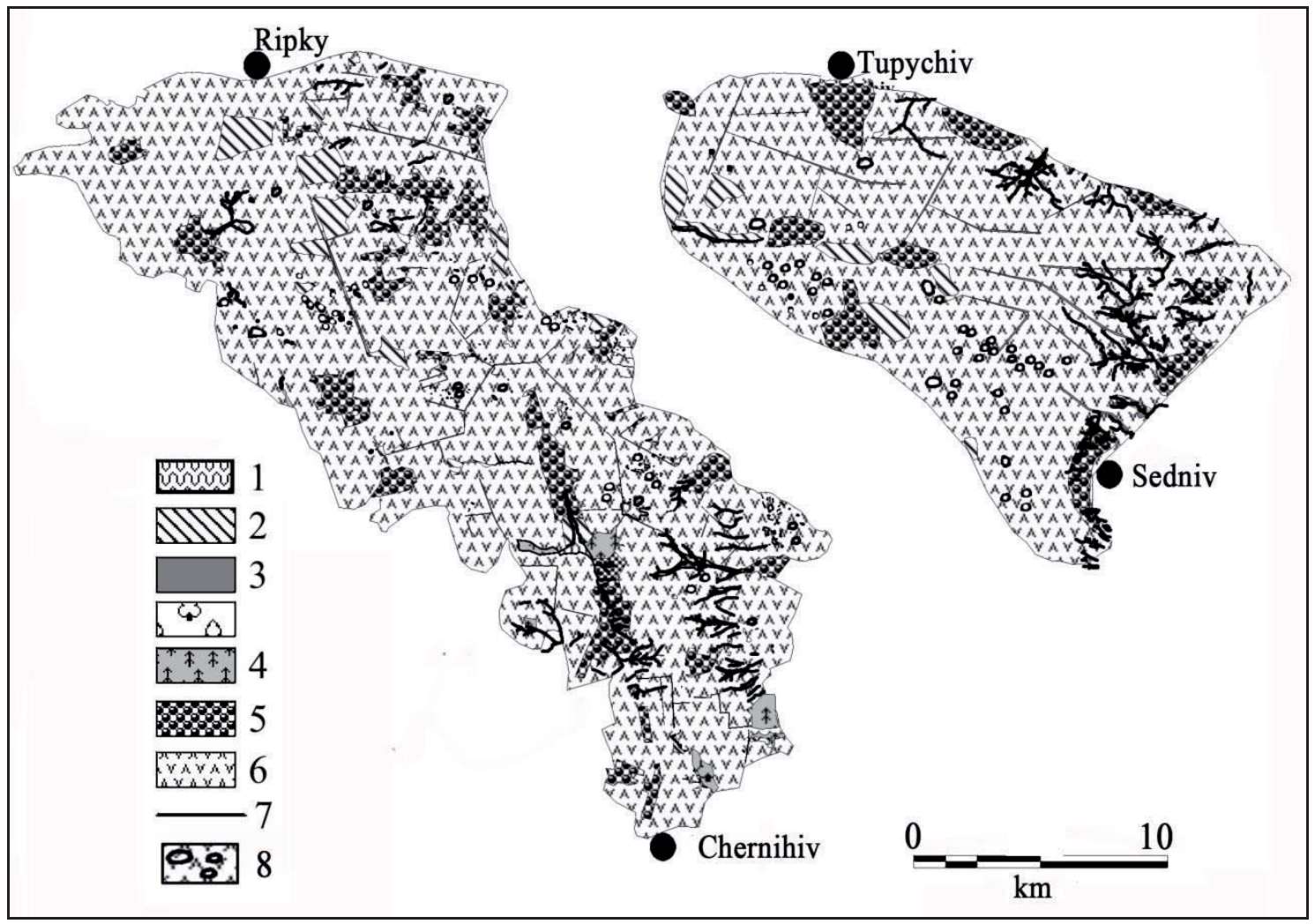

Figure 5. Vegetation map chart of the Ripky-Chernihiv and Sedniv-Tupychiv loess "island”. Symbols indicate: see Figure 4

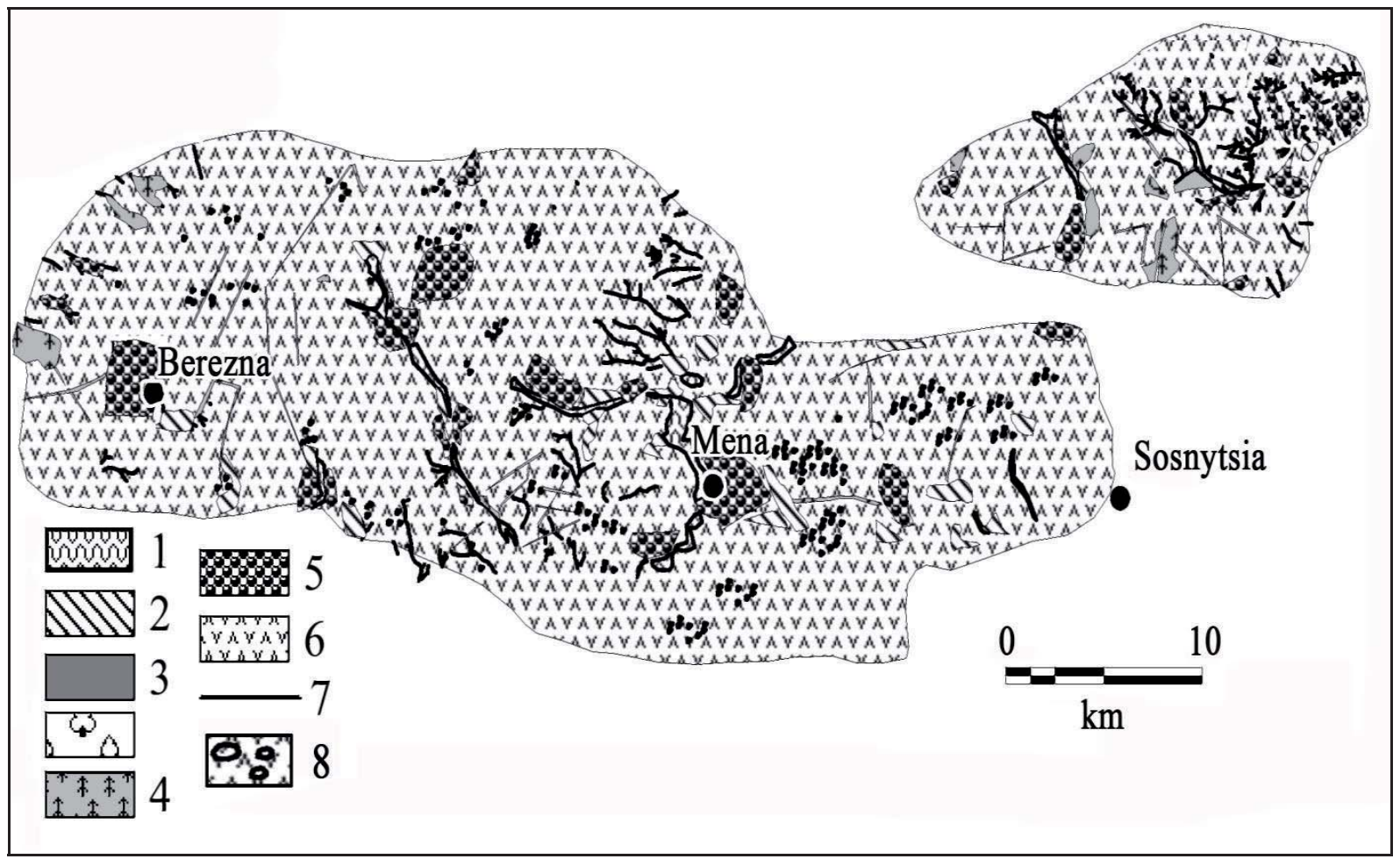

Figure 6. Vegetation map chart of Berezna-Mena-Sosnytsia loess “island”. Symbols indicate: see Figure 4 
formed in the places of anti-erosion forests planting in the ravines and gulches, are best represented on the MikhailoKotsiubynsk and Sedniv-Tupychiv loess "islands".

The communities of Digitario sanguinalis-Eragrostietea minoris Mucina, Lososová et Šilc 2016 and Bidentetea Tx. et al. ex von Rochow 1951 characterize different age states of the initial erosion of mechanically disturbed soils (Table 3).

The degree of representation of natural vegetation on the loess "islands" decreases in the following order: BereznaMena-Sosnytsia (18\%) - Ripky-Chernihiv (15\%) - SednivTupychiv (11\%) - Mykhailo-Kotsiubynsk (9\%).
The vegetation of free-flowing aquatic plants belonging to the Lemnetea O. de Bolòs et Masclans 1955 class is mostly represented on the territory of the Berezna-MenaSosnytsia and Ripky-Chernihiv loess "islands". This is due to the larger hydrological network on these loess "islands". In conditions of high humidity and high mineral nutrition, the communities of the Phragmito-Magnocaricetea Klika in Klika et Novak 1941 perennial herbs develops, first of all, of the Magnocaricetalia Pign. 1953 order. They occur in a complex with waterlogged communities of shrubs (the alliance of Salicion cinereae Th. Müller et Görs ex Passarge 1961 class Alnetea glutinosae Br.-B1. et Tx. ex

Table 3. Communities - indicators of the initial erosion of mechanically disturbed soils

\begin{tabular}{|c|c|c|c|c|}
\hline \multicolumn{2}{|c|}{ Class (according to Mucina et al., 2016) } & \multicolumn{2}{|c|}{$\begin{array}{c}\text { Digitario sanguinalis-Eragrostietea minoris } \\
\text { Mucina, Lososová et Šilc } 2016\end{array}$} & $\begin{array}{l}\text { Bidentetea Tx. et al. } \\
\text { ex von Rochow } 1951\end{array}$ \\
\hline \multicolumn{2}{|c|}{ Alliance (according to Mucina et al., 2016) } & \multicolumn{2}{|c|}{$\begin{array}{l}\text { Spergulo arvensis-Erodion cicutariae J.Tx. } \\
\text { in Passarge } 1964\end{array}$} & $\begin{array}{l}\text { Bidention tripartitae } \\
\text { Nordhagen ex Klika et } \\
\text { Hadač } 1944\end{array}$ \\
\hline \multicolumn{2}{|c|}{ Class (according to Solomakha et al., 1992) } & \multicolumn{3}{|c|}{ Class Chenopodietea Br.-B1. 1951 em Lohmeyer, J. Tx. et. R.Tx. 1961} \\
\hline \multicolumn{2}{|c|}{ Alliance (according to Solomakha et al., 1992) } & $\begin{array}{l}\text { Eu-Polygono- } \\
\text { Chenopodion polyspermi } \\
\text { V. Solm., Kost. et Sh.- } \\
\text { Sosn. } 1992\end{array}$ & $\begin{array}{l}\text { Panico-Setarion } \\
\text { Sissingh } 1946\end{array}$ & $\begin{array}{l}\text { Polygono-Chenopodion } \\
\text { Koch } 1926 \text { em. Sissingh } \\
1946\end{array}$ \\
\hline \multicolumn{2}{|c|}{$\begin{array}{l}\text { Diagnostic species (according to Solomakha } \\
\text { et al., 1992) }\end{array}$} & $\begin{array}{l}\text { Erodium cicutarium (L.) } \\
\text { L'Her., Senecio vulgaris L., } \\
\text { Alsine media L., Fumaria } \\
\text { officinalis L. }\end{array}$ & $\begin{array}{l}\text { Amaranthus retroflexus } \\
\text { L., Setaria glauca } \\
\text { (L.) P. Beauv., Setaria } \\
\text { viridis (L.) P.Beauv., } \\
\text { Convolvulus arvensis L., } \\
\text { Spergula arvensis L., } \\
\text { Rumex acetosella L. }\end{array}$ & $\begin{array}{l}\text { Tripleurospermum } \\
\text { inodorum (L.) Sch. Bip., } \\
\text { Rumex crispus L., Cirsium } \\
\text { setosum (Willd.) Besser, } \\
\text { Polygonum aviculare L., } \\
\text { Atriplex patula L., }\end{array}$ \\
\hline \multicolumn{2}{|l|}{ Places of formation } & $\begin{array}{l}\text { The areas cultivated } \\
\text { somehow or violated } \\
\text { repeatedly mechanically, } \\
\text { in particular on post- } \\
\text { sowing, abandoned lands }\end{array}$ & $\begin{array}{l}\text { The outskirts of loess } \\
\text { "islands", fields, along } \\
\text { the field roads, on dry } \\
\text { sandy and semi-sandy } \\
\text { soils, near the dwelling }\end{array}$ & $\begin{array}{l}\text { The lands that were } \\
\text { ploughed or caused to } \\
\text { multiple mechanical } \\
\text { violation more than } 5 \\
\text { years ago }\end{array}$ \\
\hline \multicolumn{2}{|c|}{ Indication of the erosion process } & $\begin{array}{l}1-2 \text { years of washouts } \\
\text { formation }\end{array}$ & $\begin{array}{l}\text { 3-4 years of washouts } \\
\text { formation }\end{array}$ & $\begin{array}{l}\text { More than } 5 \text { years, } \\
\text { the stage of washouts } \\
\text { expansion and deepening }\end{array}$ \\
\hline \multirow{4}{*}{$\begin{array}{l}\text { Area of the total } \\
\text { coverage of the class } \\
\text { communities on the } \\
\text { loess "island", } \%\end{array}$} & $\begin{array}{l}\text { Mykhailo- } \\
\text { Kotsiubynsk }\end{array}$ & 80 & 12 & 8 \\
\hline & Ripky-Chernihiv & 75 & 19 & 6 \\
\hline & Sedniv-Tupychiv & 62 & 23 & 15 \\
\hline & $\begin{array}{l}\text { Berezna-Mena- } \\
\text { Sosnytsia }\end{array}$ & 55 & 33 & 12 \\
\hline
\end{tabular}


Westhoff et al. 1946). Such complexes are often formed in the places of suffusions. Figure 7 shows the map chart of the vegetation of one of the suffusions with the area of 3.8 hectares.

Among the natural vegetation the meadow communities of the Molinio-Arrhenatheretea R.Tx. 1937 class are mostly represented on the loess "islands". These are mostly moderately hydrated meadows of the Arrhenatheretalia Pawłowski 1928 order. They were formed on rich soils in the places where the potential vegetation is the mesophilic broadleaved forests of the Carpino-Fagetea sylvaticae Jakucs ex Passarge 1968 class: Carpinion betuli Issler 1931 and Querco roboris-Tilion cordatae Solomeshch et Laivinš ex Bulokhov et Solomeshch in Bulokhov et Semenishchenkov 2015.

Small parts of broadleaved forests remained only on the territory of the Mikhailo-Kotsiubynsk loess "island". They are mainly represented by the communities of the Mercurialo perennis-Quercetum roboris Bulokhov et Solomeshch
2003 association belonging to the Querco roboris-Tilion cordatae Bulokhov et Solomeshch 2003 alliance. These communities differ from the Tilio-Carpinetum Traczyk in 1962 communities by the absence of Carpinus betulus L., Anemone nemorosa L., Hepatica Nobilis Schreb., Isopyrum thalictroides L., Oxalis acetosella L.

The Vaccinio-Piceetea Br-B1. 1939 forest types typical for Polesie are absent on the loess "islands". Instead, the forest-steppe pine forests of the Pyrolo-Pinetea sylvestris Korneck 1974 class, in which there are no characteristic species of the Vaccinio-Piceetea Br.-Bl. in Br.-Bl. et al. 1939 class (Vaccinium myrtillus, Vaccinium vitis-idaea, Trientalis europaea, Picea abies), occur. These phytocoenoses are found in the forest belts and artificial pine plantations aged 50-60 in the place of the felled broadleaved forests. In general, for the past 120 years, a slight increase in the area of forests happened thanks to the anti-erosion measures taken on the loess "islands" (Fig. 8).

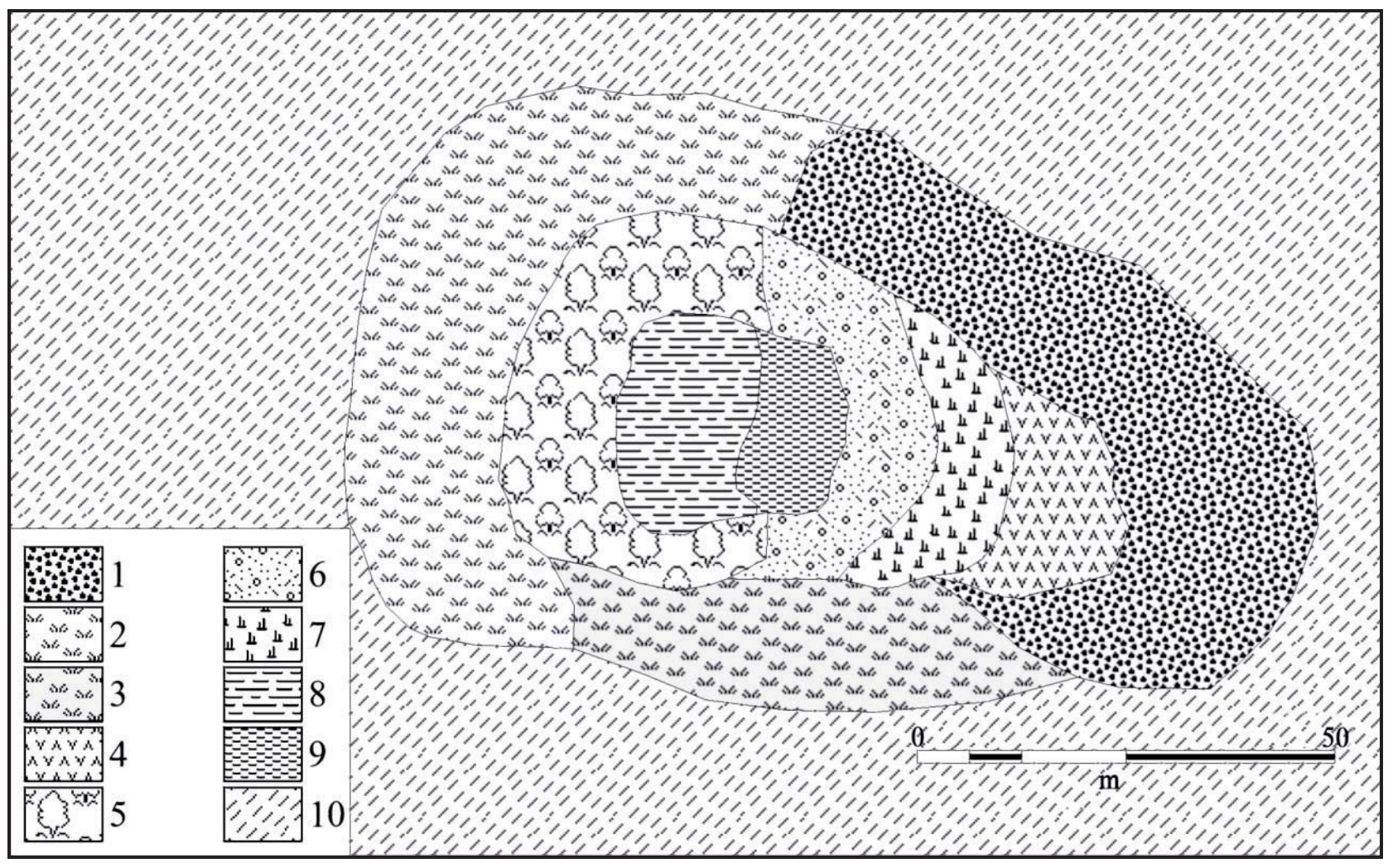

Figure 7. Map chart of suffusion vegetation on the territory of the Sedniv-Tupychiv loess "island" on the outskirts of the Ivashkivka village (Chernihiv region, Horodnia district). Associations: 1 - Convolvulo-Agropyretum repentis Felföldy (1942) 1943, 2 - Agrostis stolonifera-Potentilla anserina Oberdorfer 1983, 3 - Ranunculo-Alopecuretum geniculati R.Tx. 1937, 4 - Bidentetum tripartiti Koch 1926, 5 - Salicetum pentandro-cinereae Passarge 1961, 6 - Caricetum elatae Koch 1926, 7 - Caricetum vesicariae Br.-Bl. that Denis 1926, 8 - Deschampsietum caespitosae Horvatic 1930, 9 - LysimachioFilipenduletum Balátová-Tuláčková 1978, 10 - Centaureo-Aperetum spicae-venti V.Sl. 1989 
It should be noted that most forest belts are formed by deciduous trees. However, on the territory of the Mykhailo-Kotsiubynsk and Ripky-Chernihiv loess "islands", $P i$ nus sylvestris L. was mainly used for the formation of forest belts. In the 1960-1970s, Robinia pseudoacacia L. and Pinus sylvestris were planted on the slopes of the ravines to prevent erosion, and less often - Fraxinus excelsior L., Quercus robur L. The Rhamno-Prunetea Rivas Goday et Borja Carbonell 1961 mezoxerophilous shrub communities, which prevent erosion, occur occasionally on the slopes of the ravines of the Ripky-Chernihiv loess "island".

We offer the following organizational and economic measures of the Chernihiv Polesie loess "islands" protection:

- organization of soil protection crop rotation (it is necessary to bring the mixtures of the Fabaceae and Poaceae herbs in);

- ways of anti-erosion cultivation of soils (replacement of ploughing from "bottom-up" to the "alongside";

- increase of the areas covered by the forest, up to $10 \%$;

- prohibition of agricultural development of new territories;

- conservation of land in floodplains of rivers.

\section{Conclusions}

The causes of the mechanical degradation of loess "islands" of Chernihiv Polesie are:

- physical properties of the loess as a geologic rock that is washed out and subside easily;

- forests felling and intensive development of agriculture since the end of the 13th - the beginning of the 14th centuries;

- the use of heavy agricultural machinery and violation of the lands ploughing regime at the end of the 19th the beginning of the 21 st centuries.

The mechanical land degradation on the loess "islands" of Chernihiv Polesie is localized on the border territories. The lands at the fifth stage of erosion prevail. The largest percentage of the eroded lands is on the MykhailoKotsiubynsk (22.5\%) and Ripky-Chernihiv (15.6\%) loess "islands". We can observe the predominance of new erosive formations (the first and second stages) on these loess "islands". Plain and cavity lands with suffusion forms dominate on the Berezna-Mena-Sosnytsia loess "island" (44.7\%).

The natural vegetation of the loess "islands" of Chernihiv Polesie has been largely changed due to the agricultural use: the segetal vegetable communities pre-

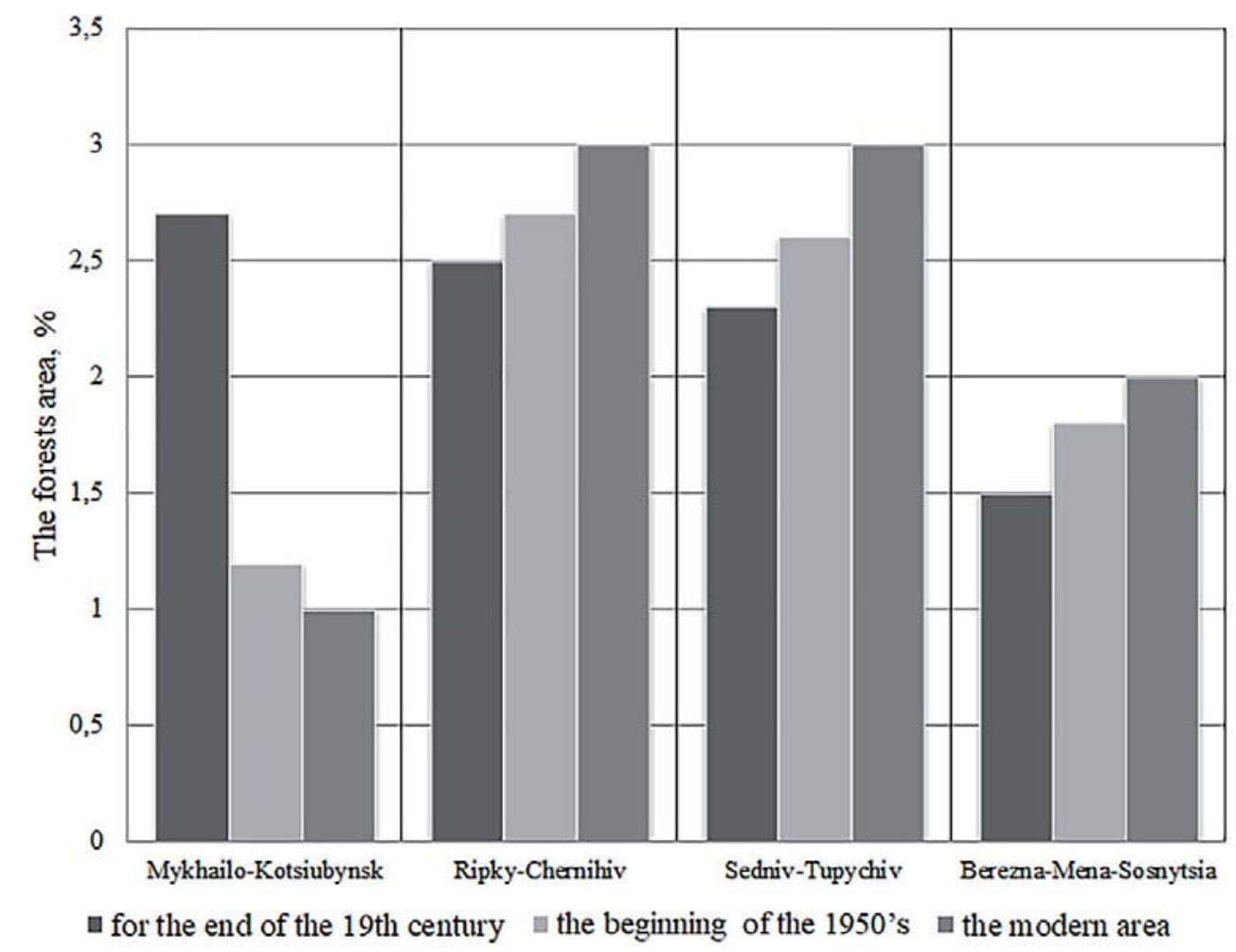

Figure 8. Dynamics of forests area percentage of the loess "islands" of Chernihiv Polesie 
dominate. Long-term use of the arable lands led not only to the stabilization of the composition of weed synusiae of agro-phytocoenoses, but also contributed to the increase of erosion and suffusion forms of the relief.

The potential places of the beginning of the mechanical degradation are post-sowing, neglected lands, which were repeatedly violated mechanically The communities of Digitario sanguinalis-Eragrostietea minoris Mucina, Lososová et Šilc 2016 and Bidentetea Tx. et al. ex von Rochow 1951 are the indicators of eroded lands at the stages of formation, expansion and deepening of washouts. The phytocenoses of the Bidentetea Tx. et al. ex von Rochow 1951 overmoistened substrates are the indicators of the initial stages of suffusion, and the complexes of the communities of Magnocaricetalia Pignatti 1953 with Salicion cinereae Th. Müller et Görs ex Passarge 1961 are the indicators of suffusion increase and deepening.

Over the past 120 years, there has been a slight increase in the area of loess phytocoenoses on the loess "islands" due to the anti-erosion planting of Pinus sylvestris L. and Robinia pseudoacacia L. Small parts of broadleaved forests remained only on the territory of the Mikhailo-Kotsiubynsk loess "island". They are mainly represented by the Querco roboris-Tilion cordatae Solomeshch et Laivinš ex Bulokhov et Solomeshch in Bulokhov et Semenishchenkov 2015 alliance. The forest-steppe communities of the Pyrolo-Pinetea sylvestris Korneck 1974 class occur in the places of formed broadleaved forests.

The agronomic, fitomeliorative and prohibitive measures, providing the ways of anti-erosion cultivation of soils, the use of ameliorative potential of plants, prohibition of agricultural development of lands, have been suggested. They can slow down the pace of the mechanical degradation of the loess "islands" of Chernihiv Polesie.

\section{References}

Akhromeiev L.M., 2008, The nature, genesis, history of the development and landscape structure of the high plains of Central Russia. Publishing house of BSU, Briansk.

Atlas of environmental conditions and natural resources of Ukrainian SSR, Main administration of geodesy and cartography at Council of ministers of the USSR, Moscow: 74-75.

Baliuk S.A. \& Tovazhnianskyi L.L., 2010, Scientific and Applied Bases of Soil Protection from Erosion in Ukraine. Publishing house of National Technical University of KhPI, Kharkiv.

Bezdukhov O.A., 2013, Influence of agricultural land use of Chernihiv region on the development of crisis ecological and geomorphological situations. Physical Geography and Geomorphology 4(11): 72-81. (http:// nbuv.gov.ua/UJRN/fiz_geo_2013_4_11).
Budko O.S., 2009, The loess "islands" of Zhytomyr and Volyn Polesie : regional problems of landscape science and geomorphology. Physical Geography and Geomorphology 56: 178-184.

Lanko A.I., 1958, On some geomorphological pequliarities of the Left Bank Polesie of the Ukrainian SSR. Bulletin of Kiev University: a series of geology and geography 1 (1): 93-102.

Korchahin A.A., 2012, Field geobotany. Methodical guidance. E.M. Lavrenko (ed.), PH Ozon.ru, Moscow.

Marynych A.M., Parkhomenko H.O., Petrenko O.M. \& Shyshenko P.H., 2003, Improved scheme of physicogeographical zoning of Ukraine. Ukrainian Geographic Journal 1(41): 21-32.

Milkov F.N., 1964, On the nature of the high plains on the Russian plain. Questions of Regional Landscape Science and Geomorphology of the USSR 8: 20-27.

Matuszkiewicz W., 2001, Przewodnik do oznaczania zbiorowisk roślinnych Polski [Guide for determination of Polish plant communities]. Wydawnictwo Naukowe PWN, Warszawa.

Mucina L., Bültmann H., Dierssen K., Theurillat J.-P., Raus T., Čarni A., Šumberová K., Willner W., Dengler J., García R.G., Chytrý M., Hájek M., Di Pietro R., Iakushenko D., Pallas J. Daniëls F.J.A., Bergmeier E., Guerra A.S., Ermakov N., Valachovič M., Schaminée J.H.J., Lysenko T., Didukh Y.P., Pignatti S., Rodwell J.S., Capelo J., Weber H.E., Solomeshch A., Dimopoulos P., Aguiar C., Hennekens S.M. \& Tichý L., 2016, Vegetation of Europe: hierarchical floristic classification system of vascular plant, bryophyte, lichen, and algal communities. Applied Vegetation Science 19(S1): 3-264. (https://onlinelibrary.wiley.com/ doi/epdf/10.1111/avsc.12257).

Pashkevych H.A., 1971, The history of vegetation of Chernigov Polesie in the late- and post-glacial time by the data of the spore-pollen analysis, Problems of palynology, International palynolongical conference. Academy of Sciences of the Ukrainian SSR, Kiev: 188-199.

Schubert F.F. \& Tuchkov P.A., 1916, Military-topographic map of Russian Empire, Row XX, Moscow: 9-10. (htpp: //www.clubclad.ru/maps/) [Accessed 20 April 2016].

Solomakha V.A., Kostylov O.V. \& Sheliah-Sosonko Yu.R., 1992, Synanthropic vegetation of Ukraine. Scientific thought, Kyiv.

Veremeichyk O.M., 2010, Results and prospects of archaeological researches of village settlements of Chernihiv Polesie. Archeology and Ancient History of Ukraine 1(3): 209-215.

Zhekulin V.S., 1982, Historical geography: object and methods. PH Science, Leningrad. 